\title{
APPLICATION OF AQUATIC PLANTS BOKASHI ON THE GROWTH AND YIELDS OF RED ONION (Allium ascalonicum L.)
}

\author{
Panji Surawijaya \\ Melhanah \\ Mochammad Anwar \\ Hastin Ernawati Nur \\ Chusnul Chotimah* \\ Raudah \\ Universitas Palangka Raya, \\ Palangka Raya, Central Kalimantan, \\ Indonesia \\ *email: \\ m.rizkifadhil@umpalangkaraya.ac.id
}

\begin{abstract}
The objectives of the study are to determine the effect of both type and dosage of aquatic plants bokashi on the growth and yield of red onion in alluvial soil. The research design used was Factorial Completely Randomized Design (CRD) consisting of two factors, namely type and the dose of aquatic plants bokashi. The first factor consisted of 3 (three) types of bokashi, i.e., giant Salvinia (Salvinia molesta), water cabbage (Pistia stratiotes) and water hyacinth (Eichornia crassipes), respectively. The second factor were 4 (four) levels of bokashi dosage which were 0 tons ha-I, 10 tons ha-I (0.2 kg/polybag), 20 tons ha-I (0.5 kg/polybag) and 30 tons ha-I $(0.8 \mathrm{~kg} / \mathrm{polybag})$. The study was conducted from March to May 2017, located in the greenhouse of the Department of Agronomy, Faculty of Agriculture, University of Palangka Raya. The results showed that there was no interaction between the type and dose of bokashi on all variables observed. The dosage of bokashi affected plant height, leaf number, fresh weight and dry weight of biomass per clump, dry weight of bulbs and tuber diameter, but did not significantly affect the number of bulbs. The bokashi type did not significantly affect all observed variables. However, the water hyacinth bokashi tended to be better than other treatments.
\end{abstract}

Keywords:

Ameliorant

Bokashi

Red Onion

Accepted

January 2019

Published

June 2019

(c) (i) ()

(C) 2019 The Authors. Published by Institute for Research and Community Services Universitas Muhammadiyah Palangkaraya. This is Open Access article under the CC-BY-SA License (http://creativecommons.org/licenses/by-sa/4.0/). DOI: https://doi.org//0.33084/anterior.v18i2.602.

\section{INTRODUCTION}

Red onion (Allium ascalonicum L.) belongs to family Liliaceae. The plant originating from Central Asia is one of the horticultural commodities that are often used as flavoring dishes. In addition, red onion also contains nutrients and compounds belonging to non-nutritional substances and enzymes that are useful for therapy, and can improve and maintain the health of the human body (Zeng et al., 2017). According to the Central Kalimantan Bureau of Statistics, production of red onion in 2014 was 125 tons with 55 ha of harvest area and an average productivity of 2.27 tons per hectare. If compared to 2013 , there was an increase of 69 tons (123.39\%) due to an increase in harvest area of 47 hectares (587.50\%) even though the productivity decreased by 4.73 tons per hectare $(67.5 \mathrm{I} \%)$. This is due to the land in the red onion production meet nutrient degradation because of the excessive chemical inputs in agricultural activities.

The reduced harvested area of the plant in Indonesia has led to the production of red onion not being able to meet the increasing needs (Central Kalimantan Bureau of Statistics, 20I4). One effort that can be done to continuously improve the yield of red onion is the application of amelioration technology. The red onion requires medium-to-clay crumbs soil, good drainage/aeration, rich in organic matter, and non acid soil reaction (soil $\mathrm{pH}: 5.6$ - 6.5). The most suitable soil for red onion is alluvial or alluvial combined with topsoil. The moist soil but no puddles is also fovored by red onion (Rismunandar, 20l I). 
The city of Palangka Raya is one city that has many rivers, lakes, and swamps. But the existence of these facilities is not properly maintained. Water bodies are covered in various types of aquatic plants. The presence of aquatic plants has a very bad effect on the condition of the waters in the city of Palangka Raya. The growth rate of aquatic plants is so fast which can cover the surface of the water. The condition can disrupt the activities of the people around the water, the water surface and aquatic biota that live in it because the process of entering light to water body is blocked so that the biota cannot receive light perfectly (Khatri \& Tyagi, 20I5).

The existence of aquatic plants actually not only has a negative impact but also has a positive impact. The aquatic plants population in each of these water bodies is abundant, but the people have no knowledge how to use these wild plants (Thomaz \& da Cunha, 2010). One alternative technology is by making compost or organic fertilizer, better known as bokashi. The use of organic materials as organic fertilizer is one alternative in an effort to increase the ability of the soil to hold water and simultaneously supply nutrients. The administration of organic matter is expected to increase soil fertility and productivity since one of the benefits of organic matter to both soil and plants are to improve soil structure, increase soil structure, increase soil uptake of water as well as a source of nutrients for plants (Lingga \& Marsono, 200I).

Salvinia molesta, Pistia stratiotes, and Eichhornia crassipes are wild plants species whose growth is fast and easy to live floating on the surface of the water (Wang et al., 2018). The plants contain elements needed by crop. The plants are source of organic matter that can be given to crops either in fresh form or in the form of compost or bokashi. The principle of making bokashi is the same as compost making which is made through fermentation by assistance of Effective Microorganisms (EM4) (Lasmini et al., 2018). The purpose of this study was to determine the best type and dosage of the aquatic plants bokashi on the growth and yield of red onion.

\section{METHODS}

The study was conducted from March to May 2017 at Green House of Agronomy Department, Agricultural Faculty, Universitas Palangka Raya. The soil used as the media was taken from embankment on the edge of the Kahayan river. The soil was taken at $0-20 \mathrm{~cm}$ depth. The red onion seed used was Pikatan variety obtained from Assessment Institute for Agricultural Technology (BPTP) Central Kalimantan. The preparation of bokashi refers to BPTP Central Kalimantan (20I2) where the source of $S$. molesta is $12 \mathrm{~kg}$, chicken manure $7 \mathrm{~kg}$, husk charcoal $1.2 \mathrm{~kg}$, rice husk $1.8 \mathrm{~kg}$, bran $1.5 \mathrm{~kg}$, dolomite 6 oz., brown sugar 2 oz, $100 \mathrm{ml} \mathrm{EM4}$ and 28 liters of water. The $P$. stratiotes and $E$. crassipes bokashi composition were the same as S. molesta bokashi. The bokashi making begins with chopping all ingredients until smooth then drying the ingredients under the sun's heat to reduce water content. The mixing of chicken manure, bran, rice husk, husk charcoal, dolomite, brown sugar, EM4 and water was done immediately after drying. The bokashi mixture was then covered using thick plastic and fermented for 14 days. The cooked and ready-to-use bokashi was characterized by a dark brown color that was not smelly.

The research design used was Factorial Completely Randomized Design. The first factor was aquatic plants as a source of bokashi consisting of S. molesta, $P$. stratiotes and $E$. crassipes. The second factor was the dosage of bokashi used involve 0 ton ha ${ }^{-1}$ (control), 10 tons $\mathrm{ha}^{-1}$ (0.2 kg per polybag), 20 tons ha-1 $(0.5 \mathrm{~kg}$ per polybag) and 30 tons $\mathrm{ha}^{-1}(0.8 \mathrm{~kg}$ per polybag), respectively. The entire treatment units were replicated three times. The application of bokashi was at the beginning of planting by immersing it into soil in polybag. After the administration of bokashi, the soil in polybag was also treated with dolomite $5.79 \mathrm{~g}$ per 
polybag and NPK Yaramila $0.87 \mathrm{~g}$ per polybag, then the planting media was incubated for one week.

The planting was done immediately after the incubation period was completed by cutting $1 / 2$ part of the tuber and treated first with the Antracol fungicide to avoid the seeds from being exposed to the fungus. The plant maintenance included watering, fertilizing, weeding and controlling pests and diseases. The pests of red onion was caterpillar, Spodoptera litura, Lyriomiza chinensis, and mites, for their control using pesticides Lannate 25 WP, whilst diseases that often affect were Coletotrichum gloesporioides, Fusarium oxysporum, and Alternaria porri, for controlling using Dhitane M45, and Cabrio top 60 WG. The watering was carried out twice a day until the age of 30 day after planting (DAP), then watering was done once a day in the morning. The harvest at the age of 60 DAP marked by the leaves have turned yellowish green and the stem became hardened. The variables observed comprised of plant height, the number of leaves, the fresh and dry weight of biomassa per clump, the number of tubers per clump, the diameter of tubers and weight of dry cloves per clump. To find out the effects of treatment and dosage were undertaken analysis of variance (F Test) at the level of $\alpha=5 \%$ and $\alpha=1 \%$. If there was a significance effects, it would be followed by LSD test with $\alpha 5 \%$.

\section{RESULTS AND DISCUSSION}

\section{Plant Height}

Based on ANOVA test, there was no interaction between the type and dose of bokashi used on all age observation on plant height. The dose of bokashi resulted the highest plant and significance difference at both 30 and 40 DAP, meanwhile, the type of bokashi was not exhibit significance difference at all age observation. The average of plant height at 40 DAP was presented at Table I.
According to Table I, the dose of bokashi 20 tons ha ${ }^{-1}$ is the dose which can cause the higest plant height $(40.06 \mathrm{~cm})$ and significance difference with both 10 tons $\mathrm{ha}^{-1}$ and control but this is not the case with the 30 tons $\mathrm{ha}^{-1}$. This is presumably because the dose of bokashi 20 tons $\mathrm{ha}^{-1}$ is the optimal dose for the red onion plant height grown on mineral soils. The use of bokashi type was not able to provide a significant increase in plant height even though there was a tendency that the type of bokashi from $E$. crassipes was proven to provide the highest plant height compared to $P$. stratiotes and $S$. molesta. The result is in line with Arbiwati (2000), who reported that bokashi from $E$. crassipes and $P$. stratiotes were the best ameliorant compared to S. molesta and Azolla, however, Azolla bokashi can increase the supply of nutrients particularly nitrogen.

Table I. Plant height of red onion at 40 DAP

\begin{tabular}{cccccl}
\hline \multirow{2}{*}{$\begin{array}{c}\text { Age } \\
\text { (DAP) }\end{array}$} & $\begin{array}{c}\text { Dose of } \\
\text { Bokashi } \\
\text { (ton ha-1) }\end{array}$ & \multicolumn{4}{c}{ Plant height per type of Bokashi $(\mathrm{cm})$} \\
\cline { 3 - 6 } & 0 & $\begin{array}{c}\text { S. } \\
\text { molesta }\end{array}$ & $\begin{array}{c}\text { P. } \\
\text { stratiotes }\end{array}$ & $\begin{array}{c}\text { E. } \\
\text { crassipes }\end{array}$ & Average \\
\hline \multirow{4}{*}{40} & 10 & 31.67 & 35.17 & 36.40 & $34.4 \mathrm{I} \mathrm{a}$ \\
& 20 & 36.23 & 36.80 & 36.17 & $36.40 \mathrm{ab}$ \\
& 30 & 39.67 & 38.67 & 41.83 & $40.06 \mathrm{c}$ \\
& Average & 36.00 & 37.83 & 38.50 & $38.78 \mathrm{bc}$ \\
\hline
\end{tabular}

Note: The average value followed by the same letter in the column show not significantly different according to the BNJ $5 \%$ test.

\section{Leaf Number}

The was no interaction between type of bokashi and dosage of bokashi used on all the age of observed. The bokashi dose treatment had a significant effect on the age of 30 and 40 DAP, whilst the type of bokashi did not significantly affect all ages of observations. The average number of leaves at 40 DAP is presented in Table 2. The treatment which did tend to have the best average number of leaves was seen in the treatment of 20 tons ha $^{-1}$ bokashi at 40 DAP with an average value of 47.44 leaves. The treatment, however, did not significantly different from those both of 10 tons $\mathrm{ha}^{-1}$ with 42.56 blades and 30 tons $\mathrm{ha}^{-1}$ with 43.78 leaves. The all treatments were significantly different from the treatment of 0 ton $\mathrm{ha}^{-1}$ bokashi dose or control with an average number of leaves 28.78 as shown in Table 2 . 
This is presumably because the administration of 20 tons $\mathrm{ha}^{-1}$ bokashi is more suitable for the needs of red onion plant growth, so that there is an increase in the number of leaves. The increase in the number of leaves in plants is influenced by nutrients present in the soil. Nitrogen $(\mathrm{N})$ is a macro nutrient for plants and is present in the soil. $\mathrm{N}$ functions to stimulate leaf growth and plant height. According to Lingga and Marsono (200I), N has benefits for plants that stimulate growth and formation of leaves and shoot as well as roots. Budianta and Ristiani (20I3), further reported that $\mathrm{N}$ functions is to produce enzymes which plays a role in leaf formation. If $\mathrm{N}$ is given excessively, it can actually lead to decreased crop production, this is, because the administration of $\mathrm{N}$ elements in a large amounts or exceeding plant needs could result in a longer vegetative phase of plants with the result that the formation of generative organs is not optimal. The consequence was in addition to decreasing productivity, the quality produced also decreases.

Table 2. The Number of Leaves at 40 DAP

\begin{tabular}{cccccc}
\hline \multirow{2}{*}{$\begin{array}{c}\text { Age } \\
\text { (DAP) }\end{array}$} & $\begin{array}{c}\text { Dose of } \\
\text { Bokashi }\end{array}$ & \multicolumn{4}{c}{ Number of leaves per type of Bokashi } \\
\cline { 3 - 6 }$\left(\right.$ ton ha $\left.^{-1}\right)$ & $\begin{array}{c}\text { S. } \\
\text { molesta }\end{array}$ & $\begin{array}{c}\text { P. } \\
\text { stratiotes }\end{array}$ & $\begin{array}{c}\text { E. } \\
\text { crassipes }\end{array}$ & Average \\
\hline \multirow{4}{*}{40} & 0 & 24.67 & 29.67 & 32.00 & $28.78 \mathrm{a}$ \\
& 10 & 42.00 & 44.00 & 41.67 & $42.56 \mathrm{~b}$ \\
& 20 & 49.67 & 48.00 & 44.67 & $47.44 \mathrm{~b}$ \\
& 30 & 45.33 & 39.33 & 46.67 & $43.78 \mathrm{~b}$ \\
\hline & Average & 40.42 & 40.25 & 41.25 & \\
\hline
\end{tabular}

Note: The average value followed by the same letter in the column show not significantly different according to the BNJ $5 \%$ test.

The E. crassipes bokashi tended to produce the highest number of leaf (4I.25) compared to other bokashi as shown in Table 2. The E. crassipes bokashi as a source of organic material can improve soil physical properties such as aeration and soil infiltration. The results of research conducted in India, showed that fresh $E$. crassipes contained $95.5 \%$ water; $3.5 \%$ organic matter; $0.04 \%$ nitrogen; I\% ash; $0.06 \%$ phosphorus as $\mathrm{P}_{2} \mathrm{O}_{5}$ and $0.20 \%$ potassium as $\mathrm{K}_{2} \mathrm{O}$. Furthermore, it was also stated that the chemical analysis experiments of E.crassipes based on dry matter produced $75.8 \%$ organic matter; I.5\% nitrogen and $24.2 \%$ ash. Analysis of ash showed $7.0 \%$ phosphorus as $\mathrm{P}_{2} \mathrm{O}_{5} ; 28.7 \%$ potassium as $\mathrm{K}_{2} \mathrm{O} ; 1.8 \%$ sodium as $\mathrm{Na}_{2} \mathrm{O} ; 12.8 \%$ calcium as $\mathrm{CaO}$ and $21.0 \% \mathrm{CCl}_{4}$, (Winata, $\left.20 \mathrm{II}\right)$.

\section{Dry Weight of Biomassa per Clump}

The both bokashi type and dose did not interact on the increasing of dry weight of biomassa per clump. The bokashi dose had a significant effect on dry weight of biomassa per clump, whereas bokashi type treatment had no significant effect. The average value of dry weight of biomassa per clump is presented in Table 3. Based on the Table 3, the treatment that producing the highest the dry weight of biomassa per clump was 20 tons $\mathrm{ha}^{-1}$ dose bokashi with an average value of $59.94 \mathrm{~g}$. The result was not significant affect with both 10 ton $\mathrm{ha}^{-1}$ and 30 tons $\mathrm{ha}^{-1}$ but this was not the case with 0 ton $\mathrm{ha}^{-1}$. The dry weight of plants is considered an indicator of plant growth, because basically the dry weight of these plants is the result of clean accumulation during plant life (Huang et al., 2019). Blok et al. (2017) added that plant growth expressed in dry weight was a manifestation of mineral supplies because almost $90 \%$ of fresh weight of plants are water and the rest $(10 \%)$ in the form of dry matter consisting of three elements, namely carbon $(\mathrm{C})$, hydrogen $(\mathrm{H})$ and oxygen (O), respectively. A small portion of dry matter is an important fraction consisting of several other elements which are absolutely needed for plant growth.

Table 3. The Dry Weight of Biomassa per Clump

\begin{tabular}{crrrr}
\hline $\begin{array}{c}\text { Dose of } \\
\text { Bokashi }\end{array}$ & \multicolumn{4}{c}{ Dry Weight of Biomassa per Clump per type of } \\
Bokashi (g) & \multicolumn{4}{c}{ Bon ha $\left.{ }^{-1}\right)$} \\
\cline { 2 - 5 } & S. molesta & P. stratiotes & E. crassipes & Average \\
\hline 0 & 27.67 & 30.00 & 37.33 & $31.67 \mathrm{a}$ \\
10 & 54.67 & 58.33 & 54.83 & $55.94 \mathrm{~b}$ \\
20 & 53.50 & 57.67 & 68.67 & $59.94 \mathrm{~b}$ \\
30 & 62.67 & 49.67 & 60.83 & $57.72 \mathrm{~b}$ \\
\hline Average & 49.63 & 48.92 & 55.42 & \\
\hline
\end{tabular}

Note: The average value followed by the same letter in the column show not significantly different according to the BNJ $5 \%$ test.

\section{Dry Weight of Biomassa per Clump}

According to Anova test, combination of both dose of bokashi and type have not gave rise to interaction on the number of bulbs per clump. The both of single 
factor had not also affected on the number of bulbs per clump. The average value of the number of bulbs per clump is presented on the Table 4.

Although the two factors did not show a significant effect, the highest number of bulb per clump was obtained in the treatment of 20 tons ha-. The absence of the influence of the two factors on red onion is in line with the results of research by Napitupulu and Winarto (2010) that the administration of organic fertilizer or NPK fertilizers does not affect the number of bulbs. The number of tillers is more determined by the variety than the fertilizing factor. The $P$. stratiotes bokashi produced the highest number of bulbs as shown in Table 4. The $\mathrm{C}$ organic content and total $\mathrm{N}$ which are quite high in $P$. stratiotes (40.5\% and $1.8 \%$ ) expected to contribute nutrients to the soil so as to reduce the use of inorganic fertilizers (Tripathi et al., 2010). The results of the analysis (Putri et al., 2013) showed that the organic matter of $P$. stratiotes compost was $22.8 \%$, while the content of fresh $P$. stratiotes organic matter was $19.6 \%$. These results indicate that both of fresh and compost of $P$. stratiotes can be used as a source of organic matter in the soil.

Table 4. The Number of Bulbs per Clump

\begin{tabular}{|c|c|c|c|c|}
\hline \multirow{2}{*}{$\begin{array}{l}\text { Dose of } \\
\text { Bokashi } \\
(\text { ton ha-1) }\end{array}$} & \multicolumn{4}{|c|}{$\begin{array}{l}\text { Number of bulbs per Clump per type of Bokashi } \\
\text { (clove) }\end{array}$} \\
\hline & S. molesta & P. stratiotes & E. crassipes & Average \\
\hline 0 & 11.67 & 12.33 & 13.33 & 12.44 \\
\hline 10 & 13.67 & 14.67 & 13.67 & 14.00 \\
\hline 20 & 15.00 & 17.67 & 13.67 & 15.44 \\
\hline 30 & 16.00 & 12.00 & 14.33 & 14.11 \\
\hline Average & 14.08 & 14.17 & 13.75 & \\
\hline
\end{tabular}

Note: The average value followed by the same letter in the column show not significantly different according to the BNJ $5 \%$ test.

\section{Dry Weight of Bulbs per Clump}

Based on the Anova test, there was no interaction between both the type and the dose of bokashi on the variable of dry weight of bulbs per clump. Between the two factors, only dosage of bokashi had been an effect on dry weight of bulbs per clump. The average value of the dry weight of bulbs per clump is presented on the Table 5.
Table 5 shows that the bokashi dose of 20 tons ha ${ }^{-1}$ produced the dry weight of bulbs per clump of $58.67 \mathrm{~g}$, which was significantly different from the control treatment, but not significantly different from the treatment of 10 tons $\mathrm{ha}^{-1}$ and 30 tons $\mathrm{ha}^{-1}$. According to Putrasamedja and Soedomo (2007), besides the environment, bulb weight was also influenced by genetic factors so there was a possibility that the bulb weight was high due to the genetic expression of the variable which was only appeared in the treatment of 20 tons $\mathrm{ha}^{-1}$.

The environment that affects the onion plant when entering the generative period is nutrient of potassium. The potassium elements play a role in enzyme activity in the synthesis of carbohydrates and proteins, as well as increase photosynthate translocation of leaves so that it can improve photosynthesis and increase bulb weight. The potassium plays an important role in plant metabolism such as in several physiological processes (Taiz and Zeiger, 2002). Potassium is also important for maintaining cell turgor pressure and water content in plants, increasing plant resistance to disease and drought, and improving yields and quality of crops. Lack of potassium can cause plants be easy to fall down, sensitive to diseases, low yield and quality, and can cause symptoms of poisoning ammonium. But the excess potassium causes plants lack nutrients $\mathrm{Mg}$ and $\mathrm{Ca}$ where nutrient $\mathrm{Ca}$ is the compilation of cell walls and important in the growth of meristem tissue, while nutrient $\mathrm{Mg}$ has an important function in the enzyme system and is a constituent of chlorophyll (Wang et al., 2013).

Table 5. Dry Weight of Bulbs per Clump

\begin{tabular}{|c|c|c|c|c|}
\hline \multirow{2}{*}{$\begin{array}{l}\text { Dose of } \\
\text { Bokashi } \\
(\text { ton ha-1) }\end{array}$} & \multicolumn{4}{|c|}{$\begin{array}{l}\text { Dry weight of bulbs per Clump per type of Bokashi } \\
(\mathrm{g})\end{array}$} \\
\hline & S. molesta & P. stratiotes & E. crassipes & Average \\
\hline 0 & 26.33 & 28.67 & 35.83 & $30.28 \mathrm{a}$ \\
\hline 10 & 52.00 & 52.33 & 52.50 & $52.28 \mathrm{~b}$ \\
\hline 20 & 51.17 & 58.50 & 66.33 & $58.67 \mathrm{~b}$ \\
\hline 30 & 60.33 & 47.67 & 58.33 & $55.44 \mathrm{~b}$ \\
\hline Average & 47.46 & 46.79 & 53.25 & \\
\hline
\end{tabular}
show not significantly different according to the BNJ $5 \%$ test. 


\section{Bulb Diameter}

The average value of higest bulb diameter was obtained by carrying out of red onion with bokashi 30 tons ha-1 as shown in Table 6. The highest value of bulb diameter was obtained with applying of red onion by the 30 tons ha $^{-1}$ bokashi as shown in Table 6 . The bulbs diameter reached $1.40 \mathrm{~mm}$ and was significantly different from the control, but not the case with dose of both 10 tons $\mathrm{ha}^{-1}$ and 20 tons $\mathrm{ha}^{-1}$. The increasing of bulbs diameter indicate that the administration of bokashi is able to contribute nutrients needed by plants to increase the yield of red onion. Gebretsadik and Dechassa (2018) states that the provision of organic fertilizer in sufficient soil causes more optimal growth of red onion.

Table 6. The Bulbs Diameter of Red Onion

\begin{tabular}{crrrr}
\hline $\left.\begin{array}{c}\text { Dose of } \\
\text { Bokashi } \\
(\text { ton ha }\end{array}{ }^{-1}\right)$ & \multicolumn{4}{c}{ Bulbs diameter per type of Bokashi $(\mathrm{mm})$} \\
\cline { 2 - 5 } & S. molesta & P. stratiotes & E. crassipes & Average \\
\hline 0 & 0.94 & 0.93 & 1.09 & $0.99 \mathrm{a}$ \\
10 & 1.29 & 1.33 & $1.4 \mathrm{I}$ & $1.34 \mathrm{~b}$ \\
20 & 1.36 & 1.29 & 1.49 & $1.38 \mathrm{~b}$ \\
30 & 1.35 & 1.44 & 1.40 & $1.40 \mathrm{~b}$ \\
\hline Average & 1.23 & 1.25 & 1.35 & \\
\hline
\end{tabular}

Note: The average value followed by the same letter in the column show not significantly different according to the BNJ $5 \%$ test.

\section{CONCLUSION}

The administration of bokashi can increase the growth of red onion on the number of leaves, fresh and dry weight of biomassa per clump, weight of bulb per clump and bulb diameter. The bokashi of $P$. stratiotes 10 tons $\mathrm{ha}^{-1}$ tends to show better results on fresh and dry weight of biomassa per clump and number of bulbs per clump compared with bokashi of S. molesta and $E$. crassipes.

\section{REFERENCES}

Arbiwati, D. 2000. Pengaruh Agregasi Tanah Inseptisol Kasar dan Vertisol akibat Pemberian Kompos Gulma Air terhadap Pertumbuhan Tanaman Jagung. Thesis. Yogyakarta: Universitas Gadjah Mada.

Blok, C., Jackson, B.E., Guo, X., de Visser, P.H.B., \& Marcelis, L.F.M. 2017. Maximum Plant
Uptakes for Water, Nutrients, and Oxygen Are Not Always Met by Irrigation Rate and Distribution in Water-based Cultivation Systems. Frontiers in Plant Science, 8(562), I15.

Budianta, D. \& Ristiani, D. 2013. Pengelolaan Kesuburan Tanah Mendukung Pelestarian Sumberdaya Lahan Dan Lingkungan. Palembang: Universitas Sriwijaya Press.

Central Kalimantan Bureau of Statistics. 2014. Data Strategis BPS Produksi Tanaman Pangan. Palangka Raya: Bureau of Statistics.

Gebretsadik, K. \& Dechassa, N. 2018. Response of Onion (Allium cepa L.) to nitrogen fertilizer rates and spacing under rain fed condition at Tahtay Koraro, Ethiopia. Scientific Reports, 8(9495), I-8.

Huang, W., Ratkowsky, D.A., Hui, C., Wang, P., Su, J., \& Shi, P. 2019. Leaf Fresh Weight Versus Dry Weight: Which is Better for Describing the Scaling Relationship between Leaf Biomass and Leaf Area for Broad-Leaved Plants? Forests, 10(256), I-19.

Khatri, N. \& Tyagi, S. 20I5. Influences of natural and anthropogenic factors on surface and groundwater quality in rural and urban areas. Frontiers in Life Science, 8, 23-29.

Lasmini, S.A., Nasir, B., Hayati, N., \& Edy, N. 2018. Improvement of soil quality using bokashi composting and NPK fertilizer to increase shallot yield on dry land. Australian Journal of Crop Science, 12, I743-I749.

Lingga, P. \& Marsono. 200I. Petunjuk Penggunaan Pupuk. Jakarta: Penebar Swadaya.

Napitupulu, D. \& Winarto, L. 2010. Pengaruh Pemberian Pupuk $\mathrm{N}$ dan K Terhadap Pertumbuhan dan Produksi Bawang Merah. Jurnal Hortikultura (Journal of Horticulture), 20, 27-35.

Putrasamedja, S. \& Soedomo, P. 2007. Evaluasi Bawang Merah yang akan Dilepas. Jurnal Pembangunan Pedesaan, 7, I33-146.

Putri, P.F., Sebayang, T. H., \& Sumarni, T. 2013. Pengaruh Pupuk N, P, K, Azolla (Azolla Pinnata) dan Apu- apu (Pistia Stratiotes) Pada Pertumbuhan dan Hasil Padi Sawah (Oryza Sativa). Jurnal Produksi Tanaman, I, 9-20. 
Rismunandar. 2011. Bertanam Kedelai. Bandung: Penerbit Ternate.

Taiz, L. \& Zeiger, E. 2002. Plant Physiology $3^{\text {rd }}$ Edition. Sundeland: Sinauer Associates.

Thomas, S.M. \& da Cunha, E.R. 2010. The role of macrophytes in habitat structuring in aquatic ecosystems: methods of measurement, causes and consequences on animal assemblages' composition and biodiversity. Acta Limnologica Brasiliensia, 22, 218-236.

Tripathi, P., Kumar, R., Sharma, A.K., Mishra, A., \& Gupta, R. 2010. Pistia stratiotes (Jalkumbhi). Pharmacognosy Review, 4, I53-160.

Wang, J., Fu, G., Li, W., Shi, Y., Pang, J., Wang, Q., Lu, W., Liu, C., \& Liu, J. 2018. The effects of two free-floating plants (Eichhornia crassipes and Pistia stratiotes) on the burrow morphology and water quality characteristics of pond loach (Misgurnus anguillicaudatus) habitat. Aquaculture and Fisheries, 3, 22-29.

Wang, M., Zheng, Q., Shen, Q., \& Guo, S. 2013. The Critical Role of Potassium in Plant Stress Response. International Journal of Molecular Sciences, 14, 7370-7390.

Winata, R.C.A. 20II. Studi Pengomposan Eceng Gondok (Eichornia crassipes) dan Jerami Padi dengan Penambahan Biodekomposer. Skripsi. Malang: Universitas Islam Negeri Maulana Malik Ibrahim.

Zeng, Y., Li, Y., Yang, J., Pu, X., Du, J., Yang, X., Yang, T., \& Yang, S. 2017. Therapeutic Role of Functional Components in Alliums for Preventive Chronic Disease in Human Being. Evidence-Based Complementary and Alternative Medicine, 2017(9402849), I-I3. 